\title{
Jewish Country Houses and Country House Studies
}

\begin{abstract}
The Jewish country houses explored in this issue represent a group of properties spread across Europe that have hitherto escaped systematic research by country house studies. In thinking about what was distinctively Jewish about the country houses of the Jewish elite this issue consolidates three significant trends in country house studies - the house, collections and wider estate as a dynamic entity shaped by a range of historical processes; the global interconnectedness of country houses; the importance of collaborative projects spanning the heritage sector and academic - and poses exciting new questions that may be profitably adapted by country house studies to advance scholarly understanding of nonJewish houses.
\end{abstract}

This special issue demonstrates that by the late nineteenth- and early-twentieth-century country houses owned, renewed and sometimes built by Jews had become a recognisable component of the European landscape. These Jewish country houses, which range in location from eighteenth-century Holland and colonial Curaçao, through Lower Austria to France, Germany, Britain and the USA, develop and extend existing trends in country house studies in exciting ways, and in their difference they raise a range of new questions that have the potential to transform the study of non-Jewish country houses. Most significantly, these houses, now considered as a group for the first time, offer a new typology of country house: one that is fundamentally cosmopolitan and European, not just defined through national characteristics.

The academic study of the country house, in Britain at least, finds its roots in the midtwentieth century where it was largely concerned with mapping the progression of artistic and architectural styles across individual properties, and the titles, marriages and mores of an endogamous elite. Much of this foundational scholarship could be found in the pages of Country Life magazine, and developed at a time when country houses were understood as a species on the edge of extinction (Mandler 1997, 265-295). However, many country houses in Britain were the unexpected beneficiaries of the post-war consumer boom becoming a significant part of the tourist economy, and the success of heritage organisations and private owners in reframing country houses as part of a British national heritage, has encouraged critical reflection on the role of the country house as a site for public history (Cannadine 2018, 9-18, Smith 2006, 115-161). Hitherto, where Jewish houses have been considered, they are usually assimilated into narrative histories that focus on collecting, display and construction of the country house from the early modern period, with limited consideration as to what made these properties different and, as they were often perceived by non-Jews, transgressive.

The revival of interest in the country house from a new generation of scholars from the mid1980 s rested upon the realization that they 'offered well-documented and often wellpreserved subjects for the material turn in cultural history' (Hall 2019). It is salutary, however, to recall the different fates of country houses across Europe in the second half of the twentieth century. Whereas in Britain, accreted collections in one place can stretch back centuries, this is not the case in much of Eastern and Central Europe. As a consequence, 
country house scholarship in Europe is more comfortable with exploring dispersed and destroyed buildings and collections. What links the successes of the most innovative and ambitious recent country house scholarship across Europe has been the ambition recast the country house and the wider estate as a dynamic archival resource, using their comparatively underexplored holdings of documents and material objects as a means of contributing to large debates about economic and political development, gender, identity, material culture and empire. The country house is no longer an end in itself, but is now instead the starting point for the opening up of broader research agendas, which recognise the country house as a nexus of rural, urban, commercial, confessional and personal relationships.

Three current trends in country house scholarship emerge as having particular relevance to our project on Jewish country houses. Firstly, the importance of connecting research into the intrinsic aesthetic qualities of a country house collection with the processes and practices that underpinned its assembly, display and (occasionally) dispersal. Secondly, the need to place individual country houses within broader international and imperial networks. Thirdly, an awareness that many country houses, in particular those now run by heritage organisations, are sites for public history and provide significant opportunities for the co-production of engaging interpretation rooted in effective collaboration between researchers and heritage professionals. Each of these trends can be further advanced through considering Jewish country houses.

As well as extending and developing existing scholarly trends, the articles in this special issue also indicate how researching Jewish country houses has the potential to open up new and innovative methodological approaches, which can profitably be applied to "mainstream" country house studies. In particular, the study of Jewish country houses, in seeking to explore what made these houses different and transgressive, can help scholars to better understand what was considered normal or acceptable. As Leora Auslander posits at the close of her contribution, could it be that Jews created a new form of country house life, one more at home with the global commercial economy that was reaching maturity by the end of the nineteenth century? Using the country house as a tool for exploring how Jews navigated their difference in a social and cultural landscape powerfully shaped by Christianity may also provide parallels with other religious and social groups whose distinctive qualities have not been considered in detail within country house studies. Running throughout these approaches is the fundamental importance of reframing the country house as a pan-European phenomenon asserting the scholarly, and heritage management benefits that are the consequence of not confining these houses, their collections and their residents to a single nation state.

One unintended consequence of the success of the country house as a visitor attraction from the second half of the twentieth century has been the tendency to fix room displays at a particular moment in time, both for conservation requirements and to support a more easily comprehensible narrative for visitors. Across Europe, country houses now under the ownership or management of heritage organisations exhibit a curatorial tension between presenting the house as a home, a lived space, or as a museum. For those in private ownership, this tension is present, but less pronounced due to the continued residence of the family. The challenge, regardless of ownership structure is to balance the desire to fix objects and rooms at a particular moment in the narrative arc of the visitor journey, with an 
awareness that the country house in the fully-function modes explored by the articles in this special issue, was a stage and site for a wide range of historical processes.

Scholars, such as Jon Stobart and Mark Rothery, emphasise the importance of understanding country houses as both 'lived spaces, created by habitual behaviour, as well as preconceived spaces of power and display' (Stobart and Rothery 2016, 72). The focus within country house studies is increasingly on the processes that combine to create the product of the country house, where every individual and each generation has the potential to make and remaking meaning in responses to social, cultural and technological change. Inherited and recently purchased objects, combined with choices made about their arrangement, can be interrogated with reference to the relationships between client, artist/architect, dealer and viewer.

Country house scholarship is now increasingly comfortable with the idea that these buildings and their occupants (both human, animal and artistic) were frequently on the move. A pressing concern of current country house scholarship is to animate the country house through uncovering the ways in which meaning was, and is, derived from a constellation of diverse interactions between people, object and place. The meaning of objects and decorative schemes could be both absolute and contingent; fixed or fluid depending on the individuals in the room, the time of year, and even the time of day. This dynamic cultural stratigraphy of the country house, with objects and people frequently on the move, can therefore provide clues to inter-generational relationships both within families and with the world beyond the walls of the estate.

The Jewish country houses considered in this issue reinforce the idea of the country house as a site where the relationship between people, object and place is dynamic, not fixed. Diana Davis's study of Gunnersbury House, for example, explores how public and private spaces evolved to answer the particular needs of the Rothschilds, predicated on their pursuit of acceptance by a non-Jewish social elite. In charting the ways in which Gunnersbury's architecture, interior decoration and social use were shaped by the family's position as Jews in Britain, which changed over time, Davis's article animates Gunnersbury to demonstrate the ways in which space could bend and flex in the service of Rothschild ambition. Crucially, these modifications of space had to avoid the perception of Jewish overreach. Leora Auslander's contribution likewise emphasises the importance of being able to modify space within the Jewish country houses of later nineteenth-century France and Germany in order to create a distinctly Jewish form, one that enabled Jews to negotiate the dichotomy at the heart of their existence: simultaneously privileged and marginalised. As with the Rothschilds at Gunnersbury, Auslander's subjects required multi-purpose spaces, which she profitably explores through considering syncretism (the simultaneity of Jewish and local/national material culture in the same space) and oscillation (spaces that move between Jewish and secular identities).

In Tom Stammers's study of Oldway Manor in Devon, the relational approach to the processes that create country houses is particularly pertinent. Stammers asserts how the Jewishness of a building should not be essentialised around particular ritual objects, or only in terms of the biography of particular items and owners. Of significance for country house studies is an awareness, reinforced by the houses in this issue, that Jewishness rarely shaped their 
architectural fabric in an overt way. Identity could be asserted and celebrated in different ways. Rather, confessional identities - be they Jewish, Catholic, Non-Conformist - may instead be found in the relationships across and between different categories of actor involved. Architect, client, decorators, gardeners, and visitors could all provide a particular approach to the country house. According to the power and wealth of the owner in question, these connections could be local, regional, national and international, or a layering of all four according to a particular moment in time.

The second significant trend in recent research into the country house is the global turn. The country house, its collections, people and wider estate increasingly function as pilot points out from the rural and the parochial, into global sites that help scholars explore the structures of power and inequality that sustained imperial expansion. The "East India Company at Home" project, recently concluded at University College London, clearly articulated the extent to which country houses should be considered as part of an entangled network stretching from Asian centres of exchange and production to a nexus of European consumer markets, as well as the importance of engaging with the 'colonial amnesia' of East India Company men and their families in 'purchasing, furnishing and populating their stately homes' (Finn and Smith 2018, 9). The 'East India Company at Home' and related endeavours including the 'Legacies of British Slave-Ownership' strongly demonstrate the importance of writing imperial histories back into country houses, particularly in those properties where there has been a conscious effort to distance or silence this dissonance (Hann and Dresser 2013, Hall, Draper, McClelland, Donnington and Lang 2014). Country houses, despite creating the fiction of separation from wider economic, social and political concerns, were thoroughly enmeshed within expanding, and frequently exploitative global networks. Recent research projects underscore the significance of understanding country houses as a product of the imperial nation state from the early eighteenth century onwards (Barczewski 2014). We know more and more about the English, Scottish, Irish, Italian, French, and Swedish country house, but work that explicitly seeks to connect across national boundaries is a limited, and recent, phenomenon. Significant strides have been made to reconnect the English and the Irish country house (Dooley, O'Riordan and Ridgway 2018), along with the wider British Atlantic world (Hague 2015). Pan-European studies have been slower to develop, but have received significant recent encouragement through the establishment of ENCOUNTER, the European Network for Country House and Estate Research in 2015 (Finch, Drymann and Frausing 2019) and the Hispanic-Anglosphere research network led by the University of Winchester (Hayward n.d.). Both these projects seek to develop new critical conceptual frameworks that connect together the study of individuals, networks and communities.

The Jewish country houses explored in this issue point the way forward. Not only are they of comparable importance in embedding more diverse and inclusive narratives within scholarly and popular understanding of the country house as the imperial dimension which has recently attracted so much focus, they also highlight the existence of other networks of exchange, commerce and mobility which have yet to be written into a pan-European history of the country house. Crucially, these Jewish country houses extend the idea of what constitutes 'international' far beyond a traditional focus on the inclusion of high status objects from other countries within the country house. International links could be manifest in both a way of thinking and in familial networks. Laura Leibman's exploration of the Dutch Sephardic Jewish pastoral ideal is rooted in both the Netherlands and Curaçao and her use of the idea of the 
rhizome is an especially powerful visual mnemonic for thinking about the enmeshed root systems of all country houses. International could also come from intersecting circles of sociability that fused different national traditions, as suggested by Diana Davis when she situates Gunnersbury as simultaneously part of an English aristocratic milieu and the material world and social mores of the elites of Paris, Frankfurt, Vienna and Naples. This notion of the density of transnational family collections is further emphasised in Auslander's contribution.

The third trend which a consideration of Jewish country houses can advance is that of coproduction and collaboration between university-based academics and heritage professionals. The idea that the country house is a significant venue for public history has gained considerable traction over the past decade (Reed 2015), arguably in response to the extensive scholarly critique as to the narratives presented and the audiences visiting country houses (Smith 2006). These narratives, which often prioritise the world view of the privileged elite, can only be shifted and changed through new types of research into country house collections. Projects interrogating links to slavery and the exploitative trading practices in India have set the trend, and a consideration of Jewish country houses offers the opportunity to extend this methodology to confront and debate anti-Semitism. The Jewish origins of country house owners mattered in a social, political and cultural context where Jewishness was stigmatised and Jews regarded as other. In seeking to enhance public awareness and understanding of the Jewish dimensions of individual country houses, this project confronts, contextualises and explains this perception of otherness, and seeks to foreground religious and cultural diversity within both national and European heritage, thereby ensuring that tangible and intangible Jewish heritage is better looked after, managed, understood and shared.

The articles in this special issue also provide new points of departure, for in seeking to answer the central question at the heart of this research project - how should we read these properties as Jewish? - they offer novel tools for interrogating and understanding the processes that combined to create both gentile and Jewish country houses across Europe; processes that new entrants to the country house world frequently sought to disguise. Jewish country houses represent a new sample against which to test established models of social change where newcomers adopt a particular aesthetic of rootedness in order to asset their claim to membership of a new social group. Within the self-fashioning of the pan-European gentry and aristocracy multiple time depths of inherited objects were of crucial importance, highlighting their membership of an elite through 'a certain hard to define but unmistakable quality' (Stobart and Rothery, 262). How did Jews create a sense of rootedness when, as many of the contributors to this issue have shown, the very issue of Jewish landownership was perceived as a threat to the established order? Productive comparisons are still to be made in exploring the similarities and difference between Jews and other trans-imperial patrician families, particularly when, like the Sassoons they were citizens and agents of empire too. Transgression could also be manifest in different types of time. As Diana Davis suggests, Gunnersbury was imprinted with the rhythms of the Jewish year, whilst Auslander asserts that the very notion of "country house time" - of leisured afternoons and polite conversation - was essential to the realpolitik of business in the age of railway time. The evocation of the form and aura of earlier aristocratic instantiations of power could contribute to the ongoing commercial and political success of those families who owned these properties. Jewish use of 
country house time therefore opens up new questions as to how assimilation, from any rising individual or group, into the changing elite of the late nineteenth century worked in practice.

The case study properties in this special issue confirm that the country house, whether in Buckinghamshire or Brandenburg, could never be a single, fixed articulation of power, wealth, status and identity (despite owners' or subsequent custodians' best intentions). Instead, the country house was the site of a broad range of competing, overlapping, and at times contradictory purposes. Rooms in country houses across Europe were anchored simultaneously in their confessional, class, local, regional, national and international identities. It is through better understanding the way in which these identities were manifested through kinship networks, social mores and material culture, and were understood by the family, staff and visitors to country houses, that research, in collaboration with heritage professionals can further animate the country house both historically and for future visitors.

\section{Notes on Contributor}

Oliver Cox is Heritage Engagement Fellow at the University of Oxford, where he leads the university's engagement with the UK and international heritage community by co-ordinating, supporting and brokering collaborative research projects. He is a historian with particular interest in the social and cultural history of the eighteenth-century British Atlantic World. His research in heritage focusses on the social, cultural and political position of the British country house in the twentieth and twenty-first centuries. Recent publications include: 'Horseracing and the Country House', in Terence Dooley and Christopher Ridgeway, The Country House: Sport \& Leisure, Dublin, 2019, and 'New Fictions: Downton and the Country House', in David Cannadine and Jeremy Musson (eds.), The British Country House: Past, Present and Future, New York, 2018.

\section{References}

Barczewski, Stephanie. 2014. Country Houses and the British Empire, 1700-1930. Manchester: Manchester University Press.

Cannadine, David and Jeremy Musson. 2018. The Country House Past, Present and Future: Great Houses of the British Isles. New York: Rizzoli.

Dooley, Terence, Maeve O'Riordan and Christopher Ridgway, eds. 2018. Woman and the Country House in Ireland and Britain. Dublin: Four Courts Press.

Finch, Jon and Kristine Dyrmann and Mikael Frausing, eds. 2019. Estate Landscapes in Northern Europe. Aarhus: Aarhus University Press.

Finn, Margot and Kate Smith, eds. 2018. The East India Company at Home: 1757-1857. London: University College London Press.

Hague, Stephen. 2015. The Gentleman's House in the British Atlantic World, 1680-1780. Basingstoke: Palgrave Macmillan.

Hall, Catherine and Nicholas Draper, Keith McClelland, Katie Donington and Rachel Lang, eds. 2014. Legacies of British Slave-Ownership: Colonial Slavery and the Formation of Victorian Britain. Cambridge: Cambridge University Press.

Hall, Michael. 2019. "Wealth and Pleasure: The Continued Celebration of Homes for the Rich." Times Literary Supplement, July 30, 2019. 
Hann, Andrew and Madge Dresser, eds. 2013. Slavery and the British Country House. Swindon: English Heritage.

Hayward, Susan, n.d. "The Hispanic-Anglosphere at Tyntesfield." Accessed August 26, 2019. https://hispanic-anglosphere.com/public-history/resources/the-hispanicanglosphere-at-tyntesfield/

Mandler, Peter. 1997. The Fall and Rise of the Stately Home. New Haven and London: Yale University Press.

Reed, Claire. 2015. "Collaborating across Heritage and Higher Education to Reveal the Global History of Osterley Park House". In New Paths to Public History, edited by Margot Finn and Kate Smith, 47-72. Basingstoke: Palgrave Macmillan.

Smith, Laurajane. 2006. Uses of Heritage. Abingdon: Routledge.

Stobart, Jon and Mark Rothery. 2016. Consumption and the Country House. Oxford: Oxford University Press. 